\title{
10 Sex education and the state
}

\author{
Norwegian schools as arenas \\ of knowledge in the 1970 s
}

Kari Hernas Nordberg

In 1974, Norwegian school authorities revised sex education in school as relationship education (samlivslare) replaced the former reproduction education (forplantningslare). This shift marked the ending of a long debate on sex education, which had accelerated at the end of the 1960s. Relationship education, the new type of sex education, was presented in an official teacher's manual. The sexuality of youths - and not only future married life - framed the education. Sexuality should encompass something broader than biological reproduction. The teacher's manual introduced the term "relationship education" in order to capture this new approach to human sexuality.

The biological function of sexuality is to ensure the continuity of mankind. Sexuality is also a foundation for contact and community, as two people share experiences, ideas, and needs, and it provides answers to one another also by physical contact. Sexuality is thus also relationship. ${ }^{1}$

In this chapter, I analyse the manual and the debates surrounding sex education, drawing attention to the Scandinavian state school as an arena of knowledge and curriculum texts as source material. The teacher's manual is a type of text that may serve as an entry point into the question formulated by Simone Lässig on "how, when, and why particular knowledge emerged or disappeared and how bodies of knowledge with different foundations stand in relation to one another". ${ }^{2}$

By the 1960s, debates on sexual liberation and contraceptives were present in society, and liberal approaches influenced sex education targeting children and adolescents. ${ }^{3}$ This challenged the curricula in many countries. Simultaneously as Norway revised its national curriculum and developed a new teacher's manual on sex education, Sweden, which was internationally renowned as the most progressive country in the field, revised and updated its sex education in school. ${ }^{4}$ In Denmark, sex education had been practised for years in a number of municipalities, but now it became mandatory in all schools. Hence, the Danish Ministry of Education issued an official manual for teaching. ${ }^{5}$ Although I focus on the Norwegian manual, there were similar developments in the three Scandinavian countries, and Scandinavia constitutes the larger context for the chapter, as the sexual knowledge circulated beyond borders. 
Historians of education have described the 1974 Norwegian national curriculum as inspired by the generation of 1968 . The teaching should be antiauthoritarian and promote gender equality. ${ }^{6}$ Although 1968 and the sexual revolution ostensibly found their expressions in the new curriculum of the Norwegian state school in the 1970s, I argue that the body of knowledge upon which the new sex education was based was not sexual radicalism but rather an assemblage of biological, Christian, psychological, and statistical knowledge. The first two types, biological and Christian knowledge, had been crucial for the establishment of the early sex education (reproduction education), while psychological and statistical knowledge had been employed in the 1960s by actors requesting a new and reformed sex education in school.

Knowledge based on different foundations was assembled in the 1974 teacher's manual, and I examine the representations of three sexual practices relevant to many youths: the use of contraceptives, masturbation, and petting. "Old" and "new" bodies of knowledge converge in the description of these practices. The manual presented knowledge that underlines the importance of sexual liberation and individual choice but within the arena of the state school. This was an arena governed by the "Christian object clause" seeking to shape the sexuality of youth in a moral, responsible manner. The manual represents an interesting type of text for studying the production of knowledge that finds a place when knowledge "belonging" to different arenas (such as medicine, therapy, and academia) circulates and converges into another arena (the state school).

\section{Sexual knowledge and the schools: texts and arenas}

As in the other two Scandinavian countries, Norwegian elementary school played an important part in the welfare state. The 1974 national curriculum laid down the principles for the sex education, and the new teacher's manual corresponded with these national guidelines. ${ }^{7}$ The national curriculum, teacher's manuals, and textbooks comprise the educational media that represent "statesanctioned" and "official" knowledge. The students are the target group for this knowledge, and at the same time, they represent the future: through school, one has the potential to shape the citizens of tomorrow. ${ }^{8}$ Although the guidelines on sex education targeted teachers, the knowledge they provided - and which the teachers were supposed to transmit - indirectly had children and youths as target groups. Furthermore, there was a risk of parents complaining, and the sex education in school did not only concern students and teachers but also parents. ${ }^{9}$

I include the teacher's manual in the category of "textbooks", although it was not intended to be read directly by the students. Textbooks and other educational media may be defined by their use or by their purpose: either as "every text practically used as a didactic tool in teaching institutions" or as "every text especially and explicitly designed to be used as a didactic instrument in teaching institutions". ${ }^{10}$ The teacher's manual belongs to the latter category. Only limited Norwegian textbook materials on sex education had been developed by the early 1970s, probably since it was not a specific school subject and 
was considered a "sensitive" topic. There were educational media that teachers could use, but these were not textbooks, rather artefacts and books that could assist in the teaching. ${ }^{11}$ This was an important distinction, as Norwegian textbooks needed authorisation by the governmental Committee for Textbooks Approval. ${ }^{12}$

The teacher's manual is particularly interesting, as it was the most specific curriculum on sex education and the Ministry of Education issued the text. Such manuals frequently represent an "anonymous" type of knowledge, as the authors are seldom identified and the texts are frequently the result of compromises between different professionals who have taken part in the production of the texts. Simone Lässig emphasises how educational media are "palimpsests" where new and old (and often contradictory) knowledge meet and where knowledge is, to a certain degree, state-sanctioned..$^{13}$ These texts may be regarded as an entrance into a point of time when "old" knowledge for some reason was replaced by "new" knowledge and the texts often offer arguments for why the "new" knowledge is now valid. ${ }^{14}$ When I use the terms "old" and "new" knowledge, this is not to be read as an indication of the quality or truthfulness of the different bodies of knowledge but rather to highlight the confrontations and melding between bodies of knowledge that were already established in an arena with bodies of knowledge that had not yet circulated in said arena. Different bodies of knowledge assemble in such texts. These are not always compatible; however, they represent knowledge on what may be considered "normal sexuality" ${ }^{15}$ In such texts, one finds the "official sexual knowledge" on what the state finds appropriate for teachers to pass on to their students. ${ }^{16}$

Although studies on textbooks in the history of science often focus on natural science and higher-level students in more narrowly defined scientific subjects (e.g., physics, chemistry), they nevertheless demonstrate how textbooks represent something more than "dogmatic and conservative vehicles of normal science". ${ }^{17}$ Marga Vicedo provides a helpful overview of arguments on why textbooks constitute an interesting source material for the history of science, and two of the many "interesting things we can do by studying textbooks" include: (1) trace the development of ideas, concepts, and hypotheses and (2) look at the social context of science. Vicedo links the interest in textbooks in the history of science to the discrediting of a "received view" of knowledge production and a related "trickle-down" model of popularisation. ${ }^{18}$ In a similar vein, it may be argued that textbooks can help us trace the circulation of knowledge and the social context of knowledge production. By studying textbooks and curricula at a certain moment of time, one may study socially shared knowledge passed on to a new generation. ${ }^{19}$

Studies of textbooks may highlight new actors and how "audiences, publishers, printers, and the silent crowd of unknown authors participated in the construction of science". ${ }^{20}$ Adam R. Shapiro emphasises how textbooks expand Robert Darnton's communication circuit "to include state (or local) regulators, regional distributors, and school principals and teachers who interact with the textbook before it reaches the student reader" ${ }^{21}$ Similarly, knowledge 
circulating within the state school will be adapted to this specific arena. Hence, such texts are particularly suited for studying the circulation of knowledge with regard to state regulation and control.

Teachers and medical doctors were the two groups of professionals who had traditionally promoted sex education, and they had often authored sex education material. Both groups had often advocated in favour of sex education in school, but it is safe to say that many teachers had a more restrictive moral approach to sex education compared to doctors. Christianity had a long, continuing influence on Norwegian schools - the "Christian object clause" stated that students should receive a Christian and moral education, and Christian values had commonly been supported by many teachers. ${ }^{22}$ Although new sexual knowledge particularly focusing on the sexuality of youths challenged the Norwegian curricula in the 1960s, there was already an established tradition of interpreting sexuality as biological reproduction that had to find its proper place in a moral social order.

\section{Bodies of knowledge in 1970s Norwegian sex education in school}

In this main part of the chapter, I delimit between four different bodies of sexual knowledge that played an important role in Norwegian sex education in the 1970s: (1) biological, (2) Christian, (3) psychological, and (4) social statistical knowledge. Before the 1970s, the traditional Norwegian sex education, the so-called reproduction education, had largely been influenced by biological and Christian knowledge. By the 1960s, psychological and statistical (social science) knowledge on sexuality influenced the public discourse on sexuality and sex education.

By biological knowledge, I refer to knowledge clearly placing human sexuality (reproduction) in the context of humans as a species. The concept of Christian knowledge is discussed by Lässig, who argues that knowledge is "a product of human activity and therefore genuinely historical. Accordingly, the history of knowledge explores what contemporaries themselves understood as knowledge in contrast to other possibly hegemonic interpretations of what it is." ${ }^{{ }^{23}}$ Religious knowledge is thus a category in its own right. By psychological knowledge, I refer to knowledge based on psychological theories on sexuality, often in a Freudian tradition of psychosexual development. Social statistical knowledge is grounded in statistics/reports on sexual behaviour and values, and this type of knowledge was produced in many Western countries during the postwar years.

Biological knowledge had constituted the foundation of Norwegian sex education in school, as it was developed by a joint effort of radical and social democratic teachers and doctors campaigning for better sexual hygiene in the interwar years. ${ }^{24}$ In 1935, medical professor Otto Lous Mohr had set up the main principles for teaching in the small pamphlet Reproduction Education as a Subject in Our Schools. Reproduction education was strictly about the facts of life and belonged to the natural science subjects. Schools were not supposed to educate students in sexual technique, nor should the subject give students 
any "emotional associations". ${ }^{25}$ Contraceptives were also too controversial to be included. The purpose of the early sex education was simply that all students should gain factual and correct knowledge on human reproduction and the most common venereal diseases. ${ }^{26}$ Mohr argued that the child was eager to gain knowledge, and when the student received true knowledge, the result would not be promiscuous behaviour, but rather the opposite. Through rational knowledge, he or she would act rationally - also in future sexual encounters. ${ }^{27}$ Sound knowledge served to protect the child. In 1939, the national curriculum included reproduction education and explicitly referred to Mohr's principles as a guide for teaching. However, due to the German occupation in 1940, neither reproduction education nor the national curriculum was implemented in the schools. This had to wait until after the Second World War.

In 1950, the Ministry of Education informed the schools that reproduction education was mandatory. A debate followed on which kind of knowledge should serve as the foundation of the teaching. Would adolescents behave in a rational manner if they acquired the so-called scientific neutral knowledge on reproduction? The main argument against biological reproduction education was that man was more than an animal and that there was no such thing as neutral knowledge. Biological knowledge on reproduction not firmly grounded in Christian morals could be potentially harmful. Man's sexual life was part of a greater social order, and the most important part of this order was the family. Hence, sex education had to focus on family life and ethics. ${ }^{28}$ Important proponents of this view were IKO (the Institute for Christian Upbringing, established in 1945) and the Christian Democratic Party. IKO produced alternative educational material to ensure that the schools were on solid moral ground, and sex education in school was thoroughly discussed in the organisation's pedagogical journal. ${ }^{29}$

A governmental committee was appointed to examine sex education in school. The committee's report was finished in 1953 but was not published until 1962, almost ten years later, as a manual for teachers. ${ }^{30}$ Although the subject was still referred to as reproduction education, the Christian moral approach to human sexuality was now emphasised and there was an attempt to harmonise this with biological knowledge. The result was a peculiar mixture of knowledge on human sexual drives and Christian ethics, such as when the manual argued for the necessity of abstinence before marriage with reference to a "protection drive": youths could suffer from "serious conflicts of the soul" if they "let their sexual drives flourish without regard to the protection drive". ${ }^{31}$ In the sex education material of the period, the use of anthropomorphisms that served to base Christian sexual morals in nature by analogies of man and animal was also a way of harmonising biological and Christian knowledge on sexuality. ${ }^{32}$

Ten years after the manual was published, this attempt to rewrite and adapt sexual nature and drives into a Christianity-based moral educational framework was criticised.

And in respect of the good intention (read: the healthy abstinence) the schools' people have simply created a new intention: the protection drive. 
This gives us the impression that this is biologically determined and equals the sexual drive. Man most certainly has many drives, but the protection drive is hard to find in serious psychological literature. ${ }^{33}$

A young psychologist, Sverre Asmervik, published the study Youth and Sexuality in 1972. As hinted in the quote, he was highly critical of the sex education in school and the knowledge it was based on. The sexuality of youth was the topic of Asmervik's study, and the book encapsulates the new knowledge and critique that challenged the Christian and biological "reproduction education": psychological (sexually radical) knowledge, social statistics on sexual behaviour, and last, but not least, an emphasis on adolescents' own sexuality.

The sexuality of youths was not a topic for the current reproduction education, as an important premise for the teaching was that procreation either took place among animals or between married couples. An increasing number of critics claimed that a troublesome gap existed between the youths' own experiences and the teaching in school. In real life, adolescents had to handle their own sexual desires and feelings, and the biological and Christian moral sex education did not offer the knowledge they required. Simultaneously, there was a related social concern with teenage pregnancies and the intertwined high number of early marriages by dispensation. ${ }^{34}$ Teenage pregnancies and early marriages clearly indicated that many youths indeed had sexual relations, and sex education that did not mention contraceptives, in fear of legitimising such relations, did nothing to reduce these figures. ${ }^{35}$

Whether or not it is possible to speak of a sexual revolution, the public discourse on sexuality was changing in the 1960s. New sexually radical ideas were in vogue. Wilhelm Reich's theories were rediscovered by the postwar generation. To Reich, the sexuality of youths was important, and it was only considered a problem due to a culture imposing sexual abstinence on the youth. ${ }^{36}$ Herbert Marcuse, "the father, grandfather, or guru of the New Left", emphasised the link between sexuality, repression, and society. ${ }^{37}$ Repressing the sexuality of children and youths posed a threat to society as a whole. To avoid future totalitarianism, anti-authoritarian parenting and schooling practices would be crucial. $^{38}$ The sexual radicalism of Marcuse and Reich provided the theoretical framework for the study of Asmervik, who wanted new sex education that acknowledged the sexuality of youths and provided knowledge counteracting the commercialisation of sexuality. When the school did not acknowledge the possibility of having a fulfilling sexual life before marriage, it was difficult to provide information on contraceptives. According to Asmervik, this was not in tune with real life, with the youths' behaviour and their values.

Asmervik had interviewed 502 youths between the ages of 16 and 19 on sex education, sexual norms, and experiences. While 60 per cent of the respondents had sexual experiences, only 3 per cent were negative towards pre-maritial sexual relations. According to Asmervik, such figures were not remarkable but implied that there was a striking inconsistency between the teaching in school and the youths' experiences. While the school emphasised that marriage was 
the proper framework for sexual relations, the youths claimed that romantic love could be the basis for sexual relations. ${ }^{39}$ The publisher presented Asmervik's book as the "Norwegian Kinsey Report". The Kinsey Reports (1948-1953) had been an expression of - and a driving force for - more open discussions on sexuality. Advocates for sex education had employed Kinsey's work, and Asmervik's study was explicitly placed in this tradition. Of course, Asmervik's work was minor compared to Kinsey's large-scale research, and the studies that directly inspired Asmervik were newer reports explicitly concerned with the sexuality of young people: Preben Hertoft's work on the sexuality of young males in Denmark (1968) and Michael Schofield's British study on The Sexual Behaviour of Young People (1965)..$^{40}$

In the debates on the sexual behaviour of youths, there were three positions: one could (as Asmervik did) embrace the sexuality of youths as normal and healthy and hence use this as a starting point for sex education. On the opposite, one could argue, as a Christian Democrat did in a parliamentary discussion in 1973, that sexual experiences should not be part of adolescence. Or one could not base sexual morals on sexual statistics. Common phenomena could very well be morally wrong. The intermediate position, typically taken by the Social Democrats, was more pragmatic: Asmervik's study showed that youths lacked proper knowledge but that they also lacked proper norms and attitudes. However, the necessary conclusion was to reform the sex education in schooland in particular include contraceptives in the teaching. ${ }^{41}$

In the 1960s and 1970s, politicians, medical doctors, psychologists, and teachers demanded a new and updated sex education. Some of them, such as Asmervik, argued that this should be based on psychological knowledge on healthy sexuality. Others did not embrace the idea of the sexuality of youths as good in itself but rather leaned on the statistics on sexual behaviour as well as the number of teenage pregnancies to argue in favour of a new sex education. A concern in the debates on sexuality and society was the "oversexualised" culture; the youths needed protection from a sexualised commercial culture. Both conservative theologians and radical social scientists could agree on the great challenge of "the grotesque and sadistic depictions of sexuality in literature and film, which confuse the youth, stimulate irresponsibility and prostitute love". ${ }^{42}$ Hence, good education could serve as a necessary counterweight to commercialised sexual texts and images.

Parts of the "oversexualised" cultural products were imported from Norway's neighbouring countries. During the postwar years, Scandinavia received a reputation as a region of liberal sexual attitudes. However, if we look at legislation on abortion and pornography, Norway was more restrictive than both Denmark and Sweden. Internationally, Sweden has been regarded as the most liberal and progressive country on sexual politics in the twentieth century, and the "Swedish sin" signified the liberalisation of pornography and the porn industry, but also state-sponsored sex education and an accepting approach to the sexuality of youths. ${ }^{43}$ Swedish self-awareness of its own progressiveness and the governmental concern regarding these issues are expressed in a 1974 report on 
sex education. The more than 800 pages long report was the result of ten years of work by a governmental committee. The report described the sex education in Norway as more conservative than in the other Nordic countries. It was based on biological knowledge and advocated abstinence during adolescence. However, the Swedish report did mention that Norwegian sex education was now changing. ${ }^{44}$

Although the four bodies of knowledge - biological, Christian, psychologi$\mathrm{cal}$, and statistical - operated in Swedish and Danish sex education, the impact of these on the sex education material and on the public debates probably differed. A major difference, which signifies an awareness of the sexuality of youths, was that the topic of contraceptives was included in the sex education texts in Sweden and Denmark. ${ }^{45}$

The lack of an updated Norwegian educational material led groups and individuals to launch their own sex education initiatives that included information on contraceptives, and many Swedish and Danish books were translated and published in Norway. In some parts of the Christian arguments against "technical" or "non-moral" sex education, one senses a fear of the consequences of this approach with regard to sexuality; if sex education included contraceptives, the school would sanction or, even worse, encourage teenagers to have an active sexual life. In this manner, the school would simultaneously undermine marriage, which was seen as pivotal for society's regulation of sexuality. The new and imported sex education material would not be founded on the "Christian objects clause". Hence, teachers who lacked textbook materials would often rely on texts that were not in accordance with Christian bodies of knowledge.

In Norway, an organised Christian political opposition had an impact on sex education in school. In the early 1970s, IKO (the Institute for Christian Upbringing) requested a governmental initiative. The so-called Oslo Plan, a teacher's guide developed for the schools in the municipality of Oslo, raised much concern. IKO published the guide in the organisation's periodical Prismet, followed by their own alternative. According to IKO, topics such as the sexual act (including foreplay and orgasm), disability and sexuality, and impotence and frigidity were inappropriate for the classroom. IKO feared that the Oslo Plan would influence other municipals in their work; hence, a critical review was crucial, and instead of looking to the capital, one should wait for the scheduled governmental work on sex education. ${ }^{46}$ In Denmark, the guide that had been used in Copenhagen had spread over the country, which is why IKO's assumption that teachers lacking guidance could turn to the Oslo Plan for advice seems rational.

In Scandinavia, as in many other Western countries, sex education was debated during the "sexual revolution" years. Although Jonathan Zimmerman argues that sex education "changed much more slowly in the 1960s and 1970s than either the heralds or the critics of the sexual revolution imagined", he points to how the number of students who received some sort of sex education rose steadily during the $1970 \mathrm{~s} .{ }^{47}$ Looking at the Norwegian sex education around 1970, the framework of the sex education itself was heavily discussed. 
The most obvious symptom of this was that the concept of "reproduction" was no longer useful, and in the new teacher's manual of 1974, it was replaced by the concept of "relationship".

\section{Conflicting bodies of knowledge? Masturbation, contraceptives, and petting}

When the Norwegian national manual was published in 1974, it was the result of a thorough process. ${ }^{48}$ In the 1960 s, compulsory Norwegian schooling was extended from seven to nine years. The students were now older when they left school, and the new teacher's manual emphasised that the teacher had to take into account the possibility that some students had sexual experiences of their own. The sexuality of youths was acknowledged in the text, and the teaching was supposed to concern the everyday life of the students. ${ }^{49}$

The new sex education of the 1970s did include topics that were relevant for the youths and that involved non-reproductive sexualities. In the following, I look at how different bodies of sexual knowledge were employed in the descriptions of masturbation, petting, and contraceptives in the new official teacher's manual.

Masturbation was by no means a new topic. The first Norwegian sex education texts, published in 1898 and aimed at teachers and parents, were indeed very much concerned with masturbation. ${ }^{50}$ These texts warned against masturbation as an unhealthy practice. However, the knowledge on child masturbation had been thoroughly challenged in the interwar period when Freud's work on children's sexual development had a profound impact on Scandinavian psychological and pedagogical knowledge. That being said, in the 1950s and 1960s, the reproduction education did not embrace masturbation as a positive and healthy practice. Although masturbation was not described as harmful but rather as common (especially among boys), there was a risk of the practice being exaggerated, which could lead to weakness and lack of initiative. ${ }^{51}$

In the early 1970s, new sex education books aimed at youths and inspired by sexual liberalism found their way to Norwegian bookstores and libraries, including books from the neighbouring sexually liberal countries: two examples are Modern Sex-Orientation for the Youths, written by Danish medical doctor Bent H. Claesson and Youth: On Sex - For the Youths and Their Parents, written by Danish journalist Lizzie Bundgaard. Claesson's book included a chapter on masturbation techniques, illustrated with photos. One photograph shows a young boy masturbating in a typical boy's room, surrounded by posters of semi-nude women and football players. The other picture is a close-up of a woman's genitalia while she masturbates. ${ }^{52}$ The journalist Bundgaard also described masturbation as good in itself. Some boys could masturbate together or have a friend do it for them, as long as everyone agreed to it. ${ }^{53}$ However, a very different kind of knowledge on masturbation and sexuality simultaneously circulated in Norway. In the book Christian Norms for Sexual Morals (1971), masturbation was not described as sinful or unhealthy in itself, but it was a 
practice that did not "create community". One should not feel guilty for masturbating; however, feelings of guilt could be regarded as a "healthy and normal reaction" if one combined masturbation with erotic fantasies of adultery. ${ }^{54}$ In this Protestant ethics, thoughts were as important as actions.

In an atmosphere where masturbation was discussed more openly, the new sex education in school could not stay silent on the subject. When the manual described masturbation, the tone was neutral. There were no explicit warnings against masturbation. In accordance with the explicit gender perspective, girls' masturbation was included.$^{55}$ Masturbation, also according to the school, was now to be regarded as a normal and legitimate expression of the sexuality of children and youths. The students should not be ashamed of masturbation, but the teacher should avoid getting into details on masturbation techniques. ${ }^{56}$ In an odd section on how the teacher's own sexuality (emotions and possible suppressions) could influence the teaching, the manual exemplifies how the teacher would react if a student masturbated in the classroom. If the teacher reacted with anger, this could provoke an "unnecessary feeling of guilt" in the student. Such a reaction by the teacher was often linked to his own anxiety: "If the teacher had analysed [his] own feelings regarding sexuality, he would probably be able to avoid such a reaction." ${ }^{57}$ Introspection into one's own feelings and emotions was an important means for managing difficult situations that could arise.

Psychological and Christian moral knowledge would also be combined in the descriptions on contraceptives, which were finally included in the education. Whether or not contraceptives could be included in teaching had been the main topic for political discussions on sex education in school in Norway in the 1960s and early 1970s, and in this regard, Norway differed from the other Scandinavian countries. Opponents of such teaching claimed that it could encourage youths to engage in sexual experimentation. When it was included in the national curriculum, it was still a very touchy topic, as the curriculum stated that one could inform on contraceptives; however, youths should not receive instructions on how to use contraceptives. ${ }^{58}$ It was not always easy to draw the line between information and instruction, such as when a teaching programme emphasised a certain contraceptive (condom with spermicidal lotion) as being well-suited for youths. Was this to be considered information, or did it cross the line to become instruction? ${ }^{59}$ In the teaching guide, the ambiguity related to contraceptives was also present on the subject of premarital sexual relations. The manual stated that youths had to decide for themselves whether they wanted to have sexual intercourse before marriage. However, if they decided to engage in intercourse, this had to be carried out in a responsible, mature manner. This included not only the use of contraceptives but also insight and knowledge regarding how sexuality was more than satisfaction of lust. The use of contraceptives presupposed mature and responsible subjects. ${ }^{60}$ The psychological dimension was a part of relationship education. Identity, self-awareness, and personal boundaries had to be discussed in the classrooms. It was not sufficient to present biological knowledge to the students. The "desired" result of 
the teaching was a responsible subject who could process the knowledge on contraceptives and reflect on sexuality in a mature and ethical manner. Such an attitude, according to the manual, would be compatible with both Christianity and humanism, and in this manner, there was an attempt to harmonise different bodies of knowledge. ${ }^{61}$

Another non-reproductive sexual practice, which involved a partner, was petting, an activity that received attention in the 1970s' sex education material. However, the state-sanctioned teacher's manual did not embrace this sexual practice.

Many youths who feel that they are not mature enough to engage in love and sexual relationships with the responsibilities and consequences this involves will nevertheless express their love by sexual play, which almost corresponds to the foreplay of sexual intercourse, often by caressing each other's genitals, which may lead to orgasm. In these situations, it may be more difficult to stop than one might have imagined. What is natural is that the "foreplay" immediately leads to sexual intercourse. It is unnatural to stop. ${ }^{62}$

In the descriptions of petting, different forms of sexual knowledge are at work. There is a clear assumption that sexuality, in its essence so to speak, equals sexual gratification, as the "natural" script would be that such practices, which are the same as "foreplay", should result in intercourse. According to the manual, "it is unnatural to stop". Orgasm by penetration thus becomes an action that signifies sexuality while petting is devalued. This is in accordance with Reich's (and other Freudian) theories on orgasm that had inspired critique of sex education. However, orgasm by penetration was not recommended for youths (most of whom were below the age of consent), so one could not recommend the "natural" result of petting. However, the problem with petting was not only physical, it was also complicated as the physical arousal could lead to emotional attachments and unrequited love. A Christian moral knowledge was at play, especially when the manual emphasised the hazards of petting with regard to girls.

Stimulating our sexual emotions without natural release may lead to tensions and dissatisfaction. An intimate relationship can lead to emotional attachments - maybe especially for the girl - that the relationship cannot provide, and that will make it difficult for her. ${ }^{63}$

Previously, sex education had emphasised the importance of protecting the girl's natural shyness. The concept of natural shyness represented "old" religious and moral knowledge, which was no longer valid. However, emotional difficulties constituted a concept more in tune with psychological sexual knowledge. Petting was considered risky behaviour as the two individuals excited each other without achieving the final orgasm by penetration, but it was also risky when it did lead to the sexual intercourse that would "naturally" follow 
such sexual acts, as the youths, caught in the moment of desire, seldom used contraceptives.

Masturbation, contraceptives, and petting were important themes in the sex education of the 1970s, and they could all be clearly linked to the sexuality of youths. Sex education that concerned the sexuality of youths and non-reproductive sexual practices involved different bodies of knowledge that highlight two interrelated dilemmas: (1) the fine line between instruction and information - and the fear of encouraging sexual experimentation and practices, and (2) the need to shape responsible youths who make responsible decisions for themselves. An underlying premise seems to be that the more detailed the instructions, the more likely that the youths will try them out. The reluctant inclusion of contraceptives may be seen in this light. Masturbation (which was and probably still is the most common sexual practice among adolescents) was mentioned and explained, but not in detail. This was (and probably still is) regarded as a very private and solitary form of sexual pleasure that the school should not get involved in. The Norwegian manual did not recommend petting; hence, there was no instruction on this either. The Danish teacher's manual did not reject petting in the same manner as the Norwegian manual, but the text emphasises that the teacher should never give information on techniques that may facilitate achieving orgasm. ${ }^{64}$

The 1974 teacher's manual was based on a national curriculum that has been described as anti-authoritarian, and although knowledge based on religion was still present, it had weakened. "How can I figure out my own sexual morals?" was a typical open question emphasised in the manual. ${ }^{65}$ The school should not instruct the student on how he or she should live but support the youth growing up in a society with less clear-cut rules and regulations. This belief in the students' capacity for reflection and decision-making may be seen in light of the so-called "psy"-knowledge that, according to Nikolas Rose, embodies "a particular way in which human beings have tried to understand themselves - to make themselves the subjects, objects, targets of truthful knowledge". ${ }^{66}$ The new sex education in the 1970s can be seen as regulation that promoted and shaped future subjects who could be "capable of bearing the burdens of liberty". ${ }^{67}$

\section{State-sanctioned knowledge: arenas, actors, and effects}

Educational media circulate within the school system, which is an arena of knowledge of utmost importance in modern society. As Lässig argues, the material has an important status as a result of the "state-sanctioned" stamp.

Anyone inquiring into the ways and settings in which knowledge is acquired, stored, applied, and altered must have an interest in consulting educational media, particularly textbooks and curricula that are mostly defined and determined by the state. ${ }^{68}$

The authoritative status may be strengthened by reading and using the material. It is important, especially for academics, to remember that a textbook may 
very well be the main source of knowledge a person consults on a subject. ${ }^{69}$ Most teachers are not experts on sex education, so what they consult is probably the manual/text at hand. It was seen as necessary to provide the teachers with an authoritative manual, as they might otherwise choose competing alternative texts. Whether they read and used the teacher's manual, and whether their teaching actually had an effect on the youths' behaviour, is obviously a different and complicated question. The use and actualisation of educational media may provide interesting perspectives for future histories of knowledge. According to the 1970s manual, the students were supposed to discuss peer pressure, sexual norms, and dilemmas that may arise. The purpose was to train the students and prepare them for possible future sexual encounters, and this potential embodied knowledge broadens the circulation of knowledge into arenas beyond the scope of this chapter.

Psychological, Christian, social statistics, and biological bodies of knowledge were combined in the teacher's manual representing Norwegian sex education in the 1970s. The same bodies of knowledge circulated within the sex education of the other two Scandinavia countries, but they circulated within three separate national school systems. A key difference was that Christian knowledge had a stronger hold on Norwegian sex education, most explicitly expressed by the long-lasting refusal to discuss contraceptives and the intertwined exclusion of the sexuality of youths. That being said, the three Scandinavian countries all had a state school system integrated into a welfare state. The social context of the production of knowledge, such as the specific arenas and actors involved, needs to be taken into account when writing histories of knowledge. Although the texts were produced within a state structure, the state often depends on organisations, experts, and pressure groups in ways that it is not always clear what the state represents or constitutes. The degree of "state involvement" in the production and circulation of knowledge is thus something that could be further explored.

In the history of knowledge, the subject under study, knowledge, is often defined as what historical actors and institutions considered knowledge. ${ }^{70}$ In this case, the actors and institutions were embedded in the state school as an arena. The institutional structure of this arena and the actors involved (children, youths, parents, teachers, experts, and politicians) shaped the production and circulation of sexual knowledge - including how the knowledge should be passed on in an appropriate manner. Hence, sex education in school cannot only be considered ideas reflecting its "time". There was no "sexual revolution" going on in the schools. The circulation of sexual knowledge was embedded in and shaped by an arena that had to promote certain values and which included teachers and students as (more or less anonymous) actors of knowledge.

As the sex education was "state-sanctioned" and as the knowledge was expected to shape the behaviour of the youths in "desired" ways, it was vulnerable to criticism. In the 1970s, changing sexual mores and different and competing bodies of knowledge did not necessarily promote clear normative implications. The regulation was more indirect, and the youths' own capabilities for reflecting upon and managing sexual choices became the "desired" 
outcome of sex education in school. Different and contradictory bodies of knowledge were not necessarily regarded as particularly problematic in the arena of the school, as the individual should make his or her own decisions. However, these decisions should be based on what was considered true sexual knowledge, and some common ground had to be found if this knowledge were to be "approved" by the state school.

\section{Notes}

1 Grunnskolerådet, Samlivslare: Forplantningen - Larerveiledning, Informasjonshefte nr. 10 (Oslo: Universitetsforlaget, 1975), 7.

2 Simone Lässig, "The History of Knowledge and the Expansion of the Historical Research Agenda”, Bulletin of the German Historical Institute 59 (2016): 40.

3 On "sexual revolution" and "permissiveness" in the history of sexuality, see, for example, Jeffrey Weeks, Sex, Politcs \& Society: The Regulation of Sexuality Since 1800 (London: Longman, 1989), 249-272; Dagmar Herzog, Sexuality in Europe: A Twentieth-Century History (New York: Cambridge University Press, 2011). On sex education, see Lutz D.H. Sauerteig and Roger Davidson, eds., Shaping Sexual Knowledge: A Cultural History of Sex Education in Twentieth Century Europe (London: Routledge, 2009); Jonathan Zimmerman, Too Hot to Handle: A Global History of Sex Education (Princeton: Princeton University Press, 2015).

4 An interesting source in this regard is the 1974 Swedish government official report that included a proposal for a new sex education manual, in addition to a thorough review of sex education and research, both in an international and historical perspective. The report is 814 pages long, and many experts had been consulted during its ten years of development. Members of the committee included well-known names such as sexologist Maj-Briht Bergström-Walan, medical doctor and chair of RFSU Thorsten Sjövall, and teacher Torsten Wickbom. See Sexual- och samlevnadsundervisning, SOU 1974:59 (Stockholm: LiberTryck, 1974). On sex education and sexuality in Sweden in the 1960s and 1970s, see Birgitta Sandström, Den välplanerade sexualiteten (Stockholm: HLS Studies in Educational Sciences, 2001); Lena Lennerhed, Frihet att njuta: Sexualdebatten i Sverige på 1960-talet (Stockholm: Norstedts, 1994).

5 Folkeskolens læseplansudvalg, Vejledning om seksualoplysning i folkeskolen (Copenhagen: Folkeskolens Læseplansudvalg, 1971). The Danish manual had been developed by medical doctor Henrik Hoffmeyer and teacher Ingolf Leth in cooperation with Folkeskolens Læseplansudvalg. Hoffmeyer and Leth were also involved in the Danish Minsistry of Education's manual from 1961: Vejledning i seksualundervisning i folkeskolen: Udgivet på foranledning af undervisningsministeriet (Copenhagen: Undervisningsministeriet 1961). There is not much research on the history of sex education in Denmark, but the subject is addressed in the thorough Danish work on school history. See Anne Katrine Gjerloff et al., Da skolen blev sin egen: 1920-1970, vol. 4 (Aarhus: Aarhus universitetsforlag, 2014), 239-241; Ning de Coninck-Smith et al., Da skolen blev alles: Tiden efter 1970, vol. 5 (Aarhus: Aarhus universitetsforlag, 2014), 241-247; Charlotte Appel and Ning de Coninck-Smith, eds., Dansk skolehistorie (Aarhus: Aarhus universitetsforlag, 2014). Representations of sexuality in Danish biology textbooks are analysed in Anne Katrine Gjerløff, "Fra celler til sex", in De røde sko: Feminisme nu, ed. Leonora Christina Skov (Aarhus: Tiderne skifter, 2002), 250-262.

6 Alfred O. Telhaug and Ole A. Mediaas, Grunnskolen som nasjonsbygger: Fra statspietisme til nyliberalisme (Oslo: Abstrakt, 2003), 220.

7 Grunnskolerådet, Samlivslare, foreword.

8 Scholars have problematised how curricula are used politically in order to "solve" social problems and have pointed to how "society's problems become the schools' curricula." 
Birgit U. Engelsen, Ideer som formet vår skole? Lareplanen som idébarer: Et historisk perspektiv (Oslo: Gyldendal, 2003), 14-15.

9 In 1971, a Danish case of complaints from parents went to the European Court of Human Rights. See Zimmerman, Too Hot to Handle, 83; Coninck-Smith et al., Da skolen blev alles, 242.

10 Antonio García-Bernal et al., "The Power of Didactic Writings: French Chemistry Textbooks of the Nineteenth Century", in Pedagogy and the Practice of Science: Historical and Contemporary Perspectives, ed. David Kaiser (Cambridge: The MIT Press, 2005), 223.

11 See Torhild Skard, "Seksualopplysning for barn og ungdom”, in Synspunkter på seksualpedagogikk, ed. Gudrun Sivertsen (Oslo: Lærerstudentens forlag, 1971); Kirke- og undervisningsdepartementet/Sosialdepartementet, NOU 1982:7: Samlivslare i skolen (Oslo: Universitetsforlaget, 1982).

12 Berit Bratholm, "Godkjenningsordningen for lærebøker, 1889-2001: En historisk gjennomgang", in Fokus på pedagogiske tekster, eds. Steffan Selander and Dagrun Skjelbred (Tønsberg: Høgskolen i Vestfold, 2001).

13 Lässig, "The History of Knowledge”, 41; Simone Lässig, "Textbooks and Beyond: Educational Media in Context(s)", Journal of Educational Media, Memory and Society 1, no. 1 (2009): 1-2.

14 On such texts as source material accounting for change, see Jane Pilcher, "Sex in Health Education: Official Guidance for Schools in England, 1928-1977”, Journal of Historical Sociology 7, no. 2/3 (2004): 205.

15 Lutz D.H. Sauerteig and Roger Davidson, "Shaping the Sexual Knowledge of the Young: Introduction", in Shaping Sexual Knowledge: A Cultural History of Sex Education in Twentieth Century Europe (London: Routledge, 2009), 1.

16 The Norwegian textbook material that I analyse in the chapter was part of the source material in Kari H. Nordberg, "Ansvarlig seksualitet: Seksualundervisning i Norge 1935-1985" (PhD diss., University of Oslo, 2014). In the work I refer to this as "statesanctioned" sexuality.

17 Garia-Belmar et al., "The Power of Didactic Writings", 243.

18 Marga Vicedo, "Introduction: The Secret Lives of Textbooks", Isis 103, no. 1 (2012): 83-86.

19 Lässig, “Textbooks and Beyond”, 5.

20 Garia-Belmar et al., "The Power of Didactic Writings", 243.

21 Adam R. Shapiro, "Between Training and Popularization: Regulating Science Textbooks in Secondary Education", Isis 103, no. 1 (2012): 106.

22 Gro Hagemann, Skolefolk: Larernes historie i Norge (Oslo: Gyldendal, 1992), 248.

23 Simone Lässig, "Religious Knowledge and Social Adaptability in the Face of Modernity", History of Knowledge, 21 July 2017, https://historyofknowledge.net/2017/07/21/ religious-knowledge-and-social-adaptability-in-the-face-of-modernity/.

24 Kari Telste, Det rare: Jenter og seksualitet gjennom 100 år (Oslo: Schibstedforlagene, 2005); Berit Nesheim, "Striden i Norge om seksualopplysning for barn fra 1890-årene til 1930årene" (Thesis in pedagogy, Universitetet i Oslo, 1973).

25 Otto L. Mohr, Forplantningslare som fag i våre skoler (Oslo: Cappelen, 1935), 12.

26 Ibid., 27-31.

27 Ibid., 63.

28 Erling Kristvik, Forplantningslare: Foreldrekunnskap (Oslo: Land og Kirke, 1951).

29 Today, the journal Prismet and the organisation IKO (Church Educational Center) describe their activities as being at the intersection between pedagogy, theology, and education. See www.iko.no.

30 "Komite til drøfting av spørsmålet om undervisning i menneskets forplantningslære i skolen", 13 December 1951 (The National Archives of Norway), RA S-3538 KUD, SRA, Statsråd L. Moens arkiv 1948-1954, Db 16, forplantningslæra.

31 Kirke- og undervisningsdepartementet, Undervisningen i forplantningslare: Rettleiing for lærere (Oslo: Kirke- og undervisningsdepartementet, 1962), 32. 
32 On the use of anthropomorphism in sex education, see Julian B. Carter, "Birds, Bees and Veneral Disease", Journal of the History of Sexuality 10, no. 2 (2001): 245.

33 Sverre Asmervik, Ungdom og seksualitet (Oslo: Gyldendal, 1972), 55.

34 Sosialdepartementet, Tenåringer og ekteskap (Oslo: Universitetsforlaget, 1972). Similar discussions took place in other countries. See, for example, Weeks, Sex, Politics \& Society, 252-256.

35 Trude Lappegård, "Sex, men ikke barn”, Samfunnsspeilet 6 (2000): 3. The number of teenage pregnancies among primiparous women was as high as 20 per cent in 1970. Thirty years later, it was less than 5 per cent.

36 Wilhelm Reich, The Sexual Revolution: Toward A Self-Governing Character-Structure (New York: Farrar Straus \& Giroux, 1969), 80.

37 John Abromeit and Mark W. Cobb, "Introduction", in Herbert Marcuse: A Critical Reader (New York: Routledge, 2004), 2.

38 Cf. Herzog's discussion on German left-wing literature in the late 1960s. Dagmar Herzog, Sex After Fascism: Memory and Morality in Twentieth-Century Germany (Princeton: Princeton University Press, 2005), 159-161.

39 Asmervik, Ungdom og seksualitet, 32.

40 Asmervik refers to Hertoft and Schofield in the thesis in pedagogy that his book was based on. He also mentions the Swedish report Om sexuallivet $i$ Sverige: Värderinger, normer, beteende $i$ sociologisk tolkning SOU 1969: 2. See Sverre Asmervik, Storbyungdom og seksualitet (Oslo: Pedagogisk forskningsinstitutt, Universitetet i Oslo). On Kinsey's influence on public discourse on sexuality after the war (in a Nordic context), see Lennerhed, Frihet att njuta.

41 "Interp. Fra repr. Aano om å fremja høgverdig etisk undervisn. og opplysn. i samlivsspørsm. for barn og ungdom m.v.", 14.2.1973, S.tid 7b, St.forh. 1972-73: 1916-1929. Both Asmervik's study and the Swedish Om sexuallivet $i$ Sverige (which presented results similar to those of Asmervik) were discussed in the Norwegian parliament. A similar, pragmatic argument was put forward by a young medical doctor (and later prime minister) Gro H. Brundtland, who used Asmervik's statistics to argue that the school had to discuss contraceptives. The appropriate argument in this case was not that the sexuality of youths had a value of its own but rather the pragmatic one: that the school could not pretend that all youths were sexually inexperienced. See Gro H. Brundtland, "Seksualundervisning i skolen", Tidsskrift for den norske Lageforening 95, no. 5 (1973): 310.

42 The editor's foreword in Øivind Foss, ed., Seksualitet og frihet (Aschehoug: Oslo, 1966), 8. Foss was a radical, left-wing theologian, but the book included articles by both the Reichian social scientist Erik Grønseth and the theologian Per Lønning, who offered diametrically opposed opinions on the question of contraceptives.

43 Pornography was legalised in Denmark already in 1967/1969 and in Sweden in 1971. Norway maintained a strict legislation. Lennerhed, Frihet att njuta, 241-242. On sexuality in Sweden, see Klara Arnberg, Motsättningarnas marknad: Den pornografiska pressens kommersiella genombrott och regleringen av pornografi $i$ Sverige 1950-1980 (Lund: Sekel, 2010); Frederick Hale, "Time for Sex in Sweden: Enhancing the Myth of the 'Swedish Sin' During the 1950s", Scandinavian Studies 75, no. 3 (2003): 351-374; Marta Kuzma et al., eds., Whatever Happened to Sex in Scandinavia? (Oslo: Office for Contemporary Art, 2011).

44 SOU, 141-142.

45 Undervisningsministeriet, Vejledning $i$ seksualundervisning $i$ folkeskolen.

46 Asbjørn Dale, "Kommentar til Oslo kommunes plan for samlivslære med seksualkunnskap for ungdomsskolen”, Prismet 2, no. 25 (1974): 68-69.

47 Zimmerman, Too Hot to Handle, 76.

48 The original text was written by pedagogue Unn Eriksen Ståsett and teacher Inger Takle (who also published other sex education materials), but there were no official authors. The original manuscript had been revised based on suggestions from medical doctors but also by teacher Inger Egeland, who had led the work on the so-called Oslo Plan, and psychologist Thore Langfeldt. "Notat om Grunnskolerådets arbeid med 
informasjonshefte nr. 10 - samlivslære, fra GSR til KUD, grunnskolekontoret 15.8.1974”, RA S-2845, KUD, Folkeskolekontoret L, Da 273, Forplantningslære 1961-1974.

49 Grunnskolerådet, Samlivslare.

50 Mathias Skard, Hvad vi bor sige til vore born om kjønslivet: Et ord til foreldre og lacere (Kristiania: Cammermeyer, 1898); O. Klykken, Fars og mors undervisning om kjonsforholdet (Kristiania: Cammermeyer, 1898).

51 Kirke- og undervisningsdepartementet, Undervisningen i forplantningslare, 30.

52 Bengt $\mathrm{H}$. Claesson, Dreng og pige, mand og kvinde: Moderne sex-orientering for unge (Copenhagen: Hans Reitzels forlag, 1969), 42-44.

53 Lizzie Bundgaard, Ung: Om sex for de unge - og dere foreldre (Oslo: Tiden, 1971), 26-27.

54 Albert Assev (ed.), Kristne normer for seksualmoral: Et ord fra kirken (Oslo: Land og kirke, 1971), 99-101.

55 Grunnskolerådet, Samlivslare, 36.

56 Ibid., 51.

57 Ibid., 12.

58 Kirke- og undervisningsdepartementet, Mønsterplan for grunnskolen (Oslo: Aschehoug, 1974).

59 Nordberg, Asvarlig seksualitet, 121.

60 Grunnskolerådet, Samlivslare, 69.

61 Ibid., 9.

62 Ibid., 64-65, emphasis added.

63 Ibid.

64 Folkeskolens læseplansudvalg, Vejledning, 33.

65 Grunnskolerådet, Samlivslare, 78.

66 Nikolas Rose, Governing the Soul: The Shaping of the Private Self (London: Free Association Books, 1989/1999), vii.

67 Ibid., viii.

68 Lässig, “Textbooks and Beyond”, 1.

69 Ibid., 2.

70 Peter Burke, What Is the History of Knowledge? (Cambridge: Polity Press, 2016), 7. 